\title{
Waste Heat Recovery of Tura Geothermal Excess Steam Using Organic Rankine Cycle
}

\author{
D. I. Permana ${ }^{1,2}$, D. Rusirawan², I. Farkas ${ }^{3}$ \\ ${ }^{1}$ Doctoral School of Mechanical Engineering, Hungarian University of Agriculture and Life Sciences, Godollo, Hungary \\ ${ }^{2}$ Department of Mechanical Engineering, Institut Teknologi Nasional, Bandung, Indonesia \\ ${ }^{3}$ Institute of Technology, Hungarian University of Agriculture and Life Sciences, Godollo, Hungary \\ E-mail: $\underline{\text { dicky91permana@itenas.ac.id }}{ }^{1,2}, \underline{\text { danir@itenas.ac.id }}^{2},{\underline{\text { Farkas.Istvan@ } \text { uni-mate.hu }^{3}}}$
}

Received 30 March 2021, Revised 12 July 2021, Accepted 20 August 2021

\begin{abstract}
A developing geothermal utilization is one of many Hungarian government efforts to generate electricity and heating applications from renewable energy sector, and to reduce fossil fuels usage due to the impact on the environment. Geothermal utilization for electricity generation has been implemented in Tura region and it is become the first geothermal plant in Hungary that producing electricity around $27 \mathrm{MW}$. The excess steam from Tura geothermal power-plant still has a potential energy that can converted to electricity and the objection in this study is implemented a heat recovery from excess steam through organic Rankine cycle (ORC) from the point of view energy and exergy analysis using different working fluids. The calculation result shows the Propane is produce the highest energy around $41 \mathrm{~kW}$ and the efficiency at $10.3 \%$, while R125 produce the lowest energy around $10.25 \mathrm{~kW}$ and the efficiency at $8.17 \%$. Moreover, based on the environmental analysis it is also found that R134a working fluid can be considered as environmentally and sustainability ORC's working fluid, compared to other working fluids, in this study.
\end{abstract}

Keywords: Generate electricity; reduce fossil fuels; energy and exergy analysis; different working fluids; efficiency.

\section{Introduction}

Hungary is striving to become an energy independent country through some actions and regulations. Hungary currently imports its energy, mostly from Russia. Natural gas makes up the larger part of the imported energy, although Hungary's natural gas consumption has decreased since 2008. 80\% of this natural gas is imported from Russia through Ukraine and Austria [1]. However, Hungary which gets most of its energy from nuclear and coal, will reduce both of fossil fuels usage due to their impact on the environment. Geothermal energy could be a viable solution for reducing the effects of global warming and dependence on fossil fuel, since the availability of geothermal energy is potentially enormous, provides a clean, reliable source of renewable energy and is suitable for base load operation [2].
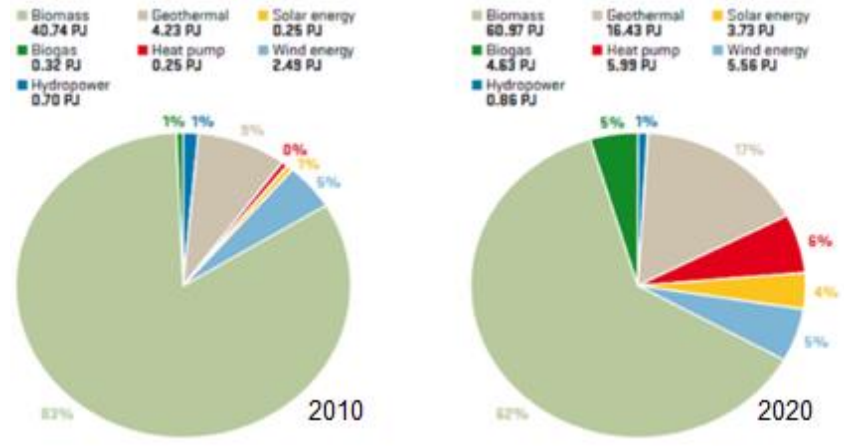

Figure 1. Distribution of renewable source used [3].

Based on Figure 1, which is describe the distribution of renewable energy for the electricity and heating sectors from
2010 to 2020 has changed. One of the concerns is management in the geothermal sector has developed quite rapidly from $4.23 \mathrm{PJ}$ in 2010 to $16.43 \mathrm{PJ}$ in 2020. This confirms that the Hungarian government makes many efforts about developing geothermal utilization, both for electricity and also for heating applications.

In Hungary itself, geothermal utilization for electricity utilization has been implemented in Tura region $(30 \mathrm{~km}$ east of Budapest) and it is become the first geothermal plant in Hungary that producing electricity. The design temperature of power plant is about $123-126^{\circ} \mathrm{C}$ with $86 \mathrm{~kg} / \mathrm{s}$ (reservoir temperature) with outflow temperature $122-125{ }^{\circ} \mathrm{C}$ total production capacity is $2.7 \mathrm{MW}$ and the excess hot water of the field is around $75-78{ }^{\circ} \mathrm{C}$ [3]. The low-medium temperature of excess hot water from the field is still have a high amount of enthalpy that can be utilised for generating electricity. However, these moderate and low-medium temperature heat sources cannot be efficiently converted into electricity through the conventional steam Rankine cycle. The ORC has been considered as most feasible cycle to generating electricity while recovering various heat sources. The ORC is same as the conventional Steam but uses low boiling temperature of organic fluids or refrigerants instead of water.

ORC has been studied both theoretically and experimentally since the 1970s for small-scale systems with yield efficiency $<10 \%$. Commercial ORC applications first appeared in the late 1970s and 1980s for medium-scale power plants developed to convert geothermal and solar energy. Nowadays, the number of ORC plant is increasingly growing with more than $1800 \mathrm{MW}$ installed worldwide from 
various heat sources such as geothermal brine, biomass and flue gas [4].

Permana et al. [5] has conducted a study of the ORC application of a flue gas source at a temperature of $180{ }^{\circ} \mathrm{C}$ from a steam power plant, where a power of $747.3 \mathrm{~kW}$ was produced using Isopentane. While Gianluca et al. [6] has investigated the cogeneration system based on a biomass boiler and a micro-Organic Rankine Cycle (ORC) unit that suitable for application in micro grids and the result is the system obtained the maximum ORC efficiency (7.3\%) and produce power around $2.5 \mathrm{~kW}$ at $150{ }^{\circ} \mathrm{C}$ and (Permana et al.) [7] has conducted an analysis of ORC from solar energy heat source in Hungary.

According to Brasz et al. [8] one of the reasons why ORC has not been widely applied is the high cost for investments that range from 1800-2875 USD/kW compared to the cost of conventional power-plant from coal-fires resources which ranges from 1200-1500 USD/kW. Where only a few companies in the world are able to engineering a low temperature turbines especially in ORC applications and among them are the Infinity Turbine, Ormat Technologies INC, Turboden and etc.

Several researches have been conducted on geothermal energy as a low-temperature heat source for ORC's from the perspective conventional energy and exergy analysis. Florian et al. [9] reported an exergy analysis for working fluid selection in an ORC geothermal. They draw conclusion, working fluid with lower critical temperature, such as Isobutane and R227ea and Isobutane are more preferable for ORC power generation. Similar research was studied by (Safa et al.) [10], they conducted a study of thermal and exergetic of the Integrated Multi Effect Desalination (MED) and Solar Rankine Cycle (SRC) in Iranian Southern Coastal Region and the result show total exergy destruction is the highest for steam generator and cavity receiver which is in the range of $61 \%$ to $64 \%$ in several cases. In this paper, evaluation of thermodynamic performance from the exhaust heat of the Tura geothermal power plant will be performed using ORC application in term of energy, exergy, and exergy sustainability aspect.

\section{Evaluation Methods}

\subsection{ORC Thermodynamic Modelling}

Figure 2 shows a simple schematic of an ORC consisting of an evaporator, turbine, condenser and pump. The heat source used for the ORC process comes from the heat of the Tura geothermal plant injection. This heat is extracted by a heat exchanger and heat transfer occurs with the working fluid which depends on its thermo-physical properties and usually have a low boiling temperature. The first and second laws of thermodynamics can be used to determine the performance of the ORC. The amount of work generated and the heat required by the ORC can be determined by the energy equilibrium equation. The equations in each component are as follows [11]:

Process 1-2, turbine:

$\dot{W}_{\text {turbine }}=\dot{m}\left(h_{1}-h_{2}\right)$,

Process 2-3, condenser:

$\dot{Q}_{\text {out }}=\dot{m}\left(h_{2}-h_{3}\right)$

Process 3-4, pump:
$\dot{W}_{\text {pump }}=\dot{m}\left(h_{4}-h_{3}\right)$,

Process 4-1, evaporator:

$\dot{Q}_{i n}=\dot{m}\left(h_{1}-h_{4}\right)$

Net power output:

$\dot{W}_{\text {net }}=\dot{W}_{\text {turbine }}-\dot{W}_{\text {pump }}=\left(h_{1}-h_{2}\right)-\left(h_{4}-h_{3}\right)$

Thermal efficiency:

$\eta_{\text {thermal }}=\frac{\dot{W}_{\text {net }}}{\dot{Q}_{\text {in }}}=\frac{\dot{W}_{\text {turbine }}-\dot{W}_{\text {pump }}}{\dot{Q}_{\text {in }}}$,

where $\dot{W}_{\text {turbine }}, \dot{W}_{\text {pump }}$ are work on turbine and pump respectively, while $\dot{m}$ ismass flow rate $(\mathrm{kg} / \mathrm{s}), h$ is specific enthalpy $(\mathrm{kJ} / \mathrm{kg})$, and $\dot{Q}_{\text {in }}, \dot{Q}_{\text {out }}$ are the heat enters and exit from the system. The Eqs. (1)-(6) are valid in the ideal condition, where all losses arisen are ignore. In actual conditions many losses occur including an increasing entropy in the compression and expansion process. In this study, the isentropic efficiency for turbine $\left(\eta_{\text {turbine }}\right)$ is set up at $80 \%$ and for pump $\left(\eta_{\text {pump }}\right)$ is $90 \%$.

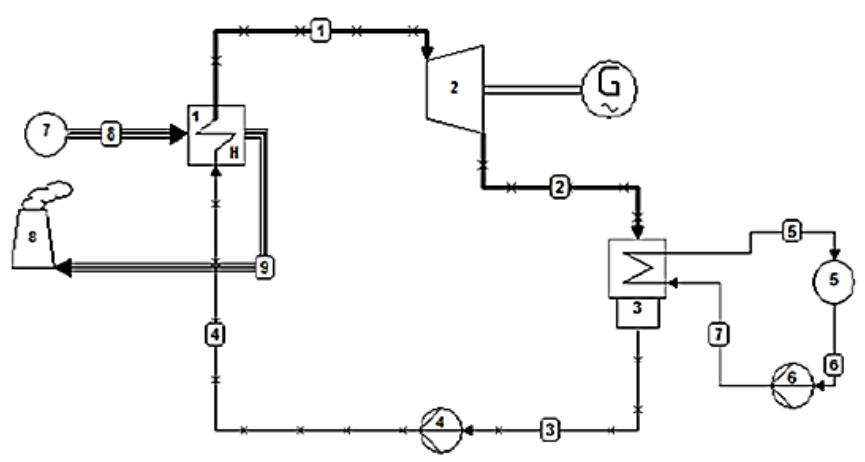

Figure 2. Schematic diagram.

The isentropic efficiency for turbine is defined as:

$\eta_{\text {turbine }}=\frac{h_{1}-h_{2}}{h_{1}-h_{2 s}}$

The isentropic efficiency for pump is defined as:

$\eta_{\text {pump }}=\frac{h_{4 s}-h_{3}}{h_{4}-h_{3}}$

For the calculation of work pump that delivered cooling water to the heat exchanger is initialize by Eq. (9), where $\gamma$ is specific weight $\left(\mathrm{N} / \mathrm{m}^{3}\right), \dot{V}$ is volumetric flow rate $\left(\mathrm{m}^{3} / \mathrm{s}\right)$, $g$ is the acceleration of gravity $\left(9.8 \mathrm{~m} / \mathrm{s}^{2}\right)$ and $H$ is the pump head.

$\gamma \dot{V} H=\dot{m}_{w} \cdot g \cdot H$

The Eq. (9) is known as the theoretical pump work $\left(\dot{W}_{p w t}\right)$ or it can be written in Eq. (10),

$\dot{W}_{p w t}=\dot{m}_{w} \cdot g \cdot H$

Meanwhile, for the efficiency of the cooling water pump can be written in Eq. (11). 
$\eta_{p w}=\frac{\dot{W}_{p w t}}{\dot{W}_{p w}}$

To get the actual work of the water-cooling pump, it is obtained by using the Eq. (12).

$\dot{W}_{p w}=\frac{\dot{m}_{w} \cdot g \cdot H}{\eta_{p w}}$

and for the mass flow rate of cooling water is shown by the Eq. (13):

$\dot{m}_{w}=\frac{\dot{m}\left(h_{2}-h_{3}\right)}{c_{p}\left(T_{w 7}-T_{w 6}\right)}$

Figure 3 shows the type of T-s cycle that depends on the pressure of working fluid in evaporator when the heat is given. If the working fluid pressure is less than the critical pressure $\left(P_{1}<P_{\text {crit }}\right)$, during heat transfer in evaporator, the working fluid will evaporate from the liquid phase to gas phase by passing through the 2-phase region, this process is called a sub-critical cycle (process cycle: 1-2-3-4-1). For another case i.e. the super-critical cycle (process cycle: $1 *$ $2 *-3-4-1)$, the pressure of working fluid is above critical pressure during heat transfer occur, in this condition a working fluid does not passed through two phases region but past the critical region directly.

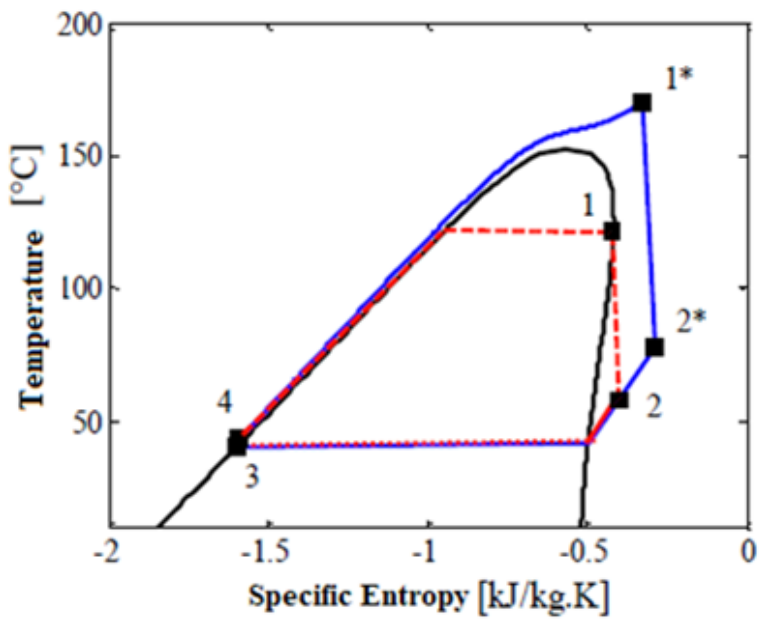

Figure 3. Process statement on T-s diagram.

Furthermore, to evaluate of comprehensive energy in the term the first and second Law of thermodynamics, exergy balance for the ORC system is performed. For a steady state condition, exergy balance can be written as [12]:

$i=\sum_{\text {in }} \dot{m}_{e x}-\sum_{\text {out }} \dot{m}_{e x}-\dot{E} X_{\text {in }}^{Q}-\dot{E} X_{\text {out }}^{Q}=T_{0} \dot{S}_{\text {gen }}$,

where $i$ is the destruction of exergy rate, $\dot{m}_{e x}$ is the exergy of working fluid mass flow, $\dot{E} X_{\text {in }}^{Q}$ and $\dot{E} X_{\text {out }}^{Q}$ are the exergy of heat input and work output and $\dot{S}_{g e n}$ is the rate of entropy generation. The thermomechanical exergy flow is expressed in Eq. (15).

$e_{x}=h-h_{0}-T_{0}\left(s-s_{o}\right)$,

where $h_{0}$ and $s_{0}$ are specific enthalpy $(\mathrm{kJ} / \mathrm{kg})$ and entropy $(\mathrm{kJ} / \mathrm{kg} . \mathrm{K})$ at dead state pressure and temperature $\left(P_{0}, T_{0}\right)$ which be used in this study are $0.101325 \mathrm{Mpa}(1 \mathrm{~atm})$ and 5 ${ }^{\circ} \mathrm{C}$, respectively. The actual exergy flow $\left(\dot{E}_{X i}\right)$, exergy efficiency and exergy destruction can be evaluated using Eqs. (16)-(19) [12].

Process 1-2, turbine:

$\dot{E}_{X 1}=\dot{E}_{X 2}+\dot{W}_{\text {turbine }}+\dot{E}_{\text {Dturbine }}$,

Process 2-3, condenser:

$\dot{E}_{X 2}=\dot{E}_{X 3}+\dot{E}_{D \text { condenser }}$

Process 3-4, pump:

$\dot{E}_{X 3}+\dot{W}_{\text {pump }}=\dot{E}_{X 4}+\dot{E}_{\text {Dpump }}$,

Process 4-1, evaporator:

$\left(1-\frac{T_{0}}{T_{i n}}\right)+Q_{\text {in }}+\dot{E}_{X 4}=\dot{E}_{X 1}+\dot{E}_{\text {Devap }}$

where $\dot{E}_{\text {Dturbine }}, \dot{E}_{\text {Dcondenser }}, \dot{E}_{\text {Devap }}, \dot{E}_{\text {Dpump }}$ denote as destruction of exergy in turbine, condenser, pump and evaporator, respectively. A further breakdown in the actual exergy flows in the components is present by Eqs. (20)-(23) and component exergy efficiency are presented by Eqs. (24)(27) [12]:

$$
\begin{aligned}
& \dot{E}_{X 1}=\dot{m}_{1}\left\|C_{p}\left[T_{1}-T_{0}\right]-T_{0}\left\{c_{p} \ln \left[\frac{T_{1}}{T_{0}}\right]-R \ln \left[\frac{P_{1}}{P_{0}}\right]\right\}\right\|, \\
& \dot{E}_{X 2}=\dot{m}_{2}\left\|C_{p}\left[T_{2}-T_{0}\right]-T_{0}\left\{c_{p} \ln \left[\frac{T_{2}}{T_{0}}\right]-R \ln \left[\frac{P_{2}}{P_{0}}\right]\right\}\right\|, \\
& \dot{E}_{X 3}=\dot{m}_{3}\left\|C_{p}\left[T_{3}-T_{0}\right]-T_{0}\left\{c_{p} \ln \left[\frac{T_{3}}{T_{0}}\right]-R \ln \left[\frac{P_{3}}{P_{0}}\right]\right\}\right\|, \\
& \dot{E}_{X 4}=\dot{m}_{4}\left\|C_{p}\left[T_{4}-T_{0}\right]-T_{0}\left\{c_{p} \ln \left[\frac{T_{3}}{T_{0}}\right]-R \ln \left[\frac{P_{4}}{P_{0}}\right]\right\}\right\|, \\
& \psi_{\text {turbine }}=\frac{m_{r e f} C_{p}\left[T_{1}-T_{2}\right]}{\dot{E}_{X 1}-\dot{E}_{X 2}}, \\
& \psi_{\text {pump }}=\frac{\dot{E}_{X 4}}{\left[\frac{C_{p}\left[T_{1}-T_{2}\right]}{\eta_{p u m p}},\right.}, \\
& \psi_{\text {evap }}=\frac{\dot{E}_{X 1}-\dot{E}_{X 4}}{\left[1-\frac{T_{0}}{T_{Q}}\right] Q_{i n}}, \\
& \psi_{\text {cond }}=\frac{\dot{E}_{X 2}-\dot{E}_{X 3}}{\dot{E}_{X 3}},
\end{aligned}
$$

where $\psi_{\text {turbine }}, \psi_{\text {pump }}, \psi_{\text {evap }}, \psi_{\text {cond }}$ denote as efficiency of exergy (\%) in turbine, pump, evaporator and condenser, respectively, meanwhile $C_{p}$ and $R$ are the specific heat at pressure constant (J/kg.K) and universal gas constant (8.3154 J/mol.K), respectively.

Exergy analysis is not only to measure how much energy quality is available in a system but can be used to improve the performance of both the economic and environmental aspect. Furthermore, in this study the role of exergy as a method to measure the sustainability of a process and system is used. Some researchers call it the exergy sustainability index (ESI) or the thermo-sustainability index (TSI). ESI is also a powerful parameter among other indicators. It accesses the degree of sustainability, and it can be derived 
from the respective exergy balanced equations for each cycle and investigated of ESI are presented by Eqs. (28)-(31) [13].

Exergy waste ratio (EWR):

$E W R=\frac{\text { Overall exergy waste }}{\text { overall exergy } \text { input }}$

Exergy efficiency:

$\psi_{\text {overall }}=\frac{\dot{E}_{X o u t}}{\dot{E}_{X i n}}$

Environmental effect factor (EEF):

$E E F=\frac{\text { Waste exergy ratio }}{\text { Exergy ef ficiency }}$

Exergy sustainability index (ESI):

$E S I=\frac{1}{\text { Environmental effect factor }}$.

This study consider the following assumptions: i) steady state condition, ii) heat losses and the pressure drop in component systems are neglected, iii) the inlet temperature of turbine were set at $68^{\circ} \mathrm{C}$, iv) the temperature of cooling water were set at $10{ }^{\circ} \mathrm{C}, \mathrm{v}$ ) the pump and turbine isentropic efficiency were set at $90 \%$ and $80 \%$, respectively, vi) The exergy of hot gas leaving the evaporator and the exergy of water entering and leaving from the condenser are negligible.

\subsection{Working Fluids Selection}

The main difference between ORC and steam Rankine cycle is the working fluid that used in each cycle. Water is used working fluid in steam Rankine cycle while there are a lots of different working fluids which can be used in ORC. The thermo-physical, safety and environmental properties vary from one working fluid to another. The choice of the right working fluid is the most importance key for the cycle efficiency, net work out and etc. The choice of working fluid has been widely studied in scientific journals, both theoretically and practically but the optimal selection of working fluid is based on the characteristics of the heat source.

Table 1. Working fluids selection [14]

\begin{tabular}{lllll}
\hline Parameters & R125 & R143a & R22 & Propane \\
\hline Tcritital $\left({ }^{\circ} \mathrm{C}\right)$ & 66.23 & 72.71 & 96.14 & 96.74 \\
Pcritical $(\mathrm{MPa})$ & 3.62 & 3.77 & 4.99 & 4.25 \\
Molar Mass $(\mathrm{g} / \mathrm{mol})$ & 120.02 & 84.04 & 86.47 & 44.1 \\
Type & Isentropic & Isentropic & Wet & Wet \\
ODP & 0 & 0 & 0.04 & 0 \\
GWP & 2740 & N/A & 1790 & N/A \\
$\begin{array}{l}\text { ASHRAE safety } \\
\text { group }\end{array}$ & A1 & A2 & A1 & B3 \\
LEL $(\%$ Vol) & N/A & 7.1 & & \\
UEL $(\%$ Vol $)$ & N/A & 16.1 & N/A & 2.1 \\
\hline
\end{tabular}

Table 1 is the refrigerant chosen as the working fluid for the ORC analysis where the refrigerant selection matches the waste heat characteristics of the Tura geothermal plant, which is at a temperature of $68-78^{\circ} \mathrm{C}$ for waste heat that has a temperature below $100{ }^{\circ} \mathrm{C}$, it is better to choose a working fluid that has a critical temperature that is close to the temperature of the residual heat source and works on subcritical expansion. It can be seen that the four selected working fluids have a critical temperature that works in the residual heat source temperature range. Other factors to consider are Ozone Depleting Potential (ODP) and (Global Warming Potential (GWP) where these two factors determine how much the working fluid can affect the environment, in this case in terms of ozone and global warming [15]. For example, the four working fluids (Propane, R125, R143a, R22) have an ODP of 0 which means the working fluids have no effect with the ozone layer. Meanwhile, according to ASHRAE safety level parameter was added to determine which working fluid is the safest to use in terms of flammability and toxicity.

It can be seen in Figure 4 which is a chart of the level of fire and the level of poisoning of a working fluid represented by letters and numbers. For example, R125 and R22 are classified as A1 where both working fluids have no fire potential and low toxicity. Meanwhile, Propane which has a B3 classification according to ASHRAE is a working fluid that has a high potential for fire and toxicity.

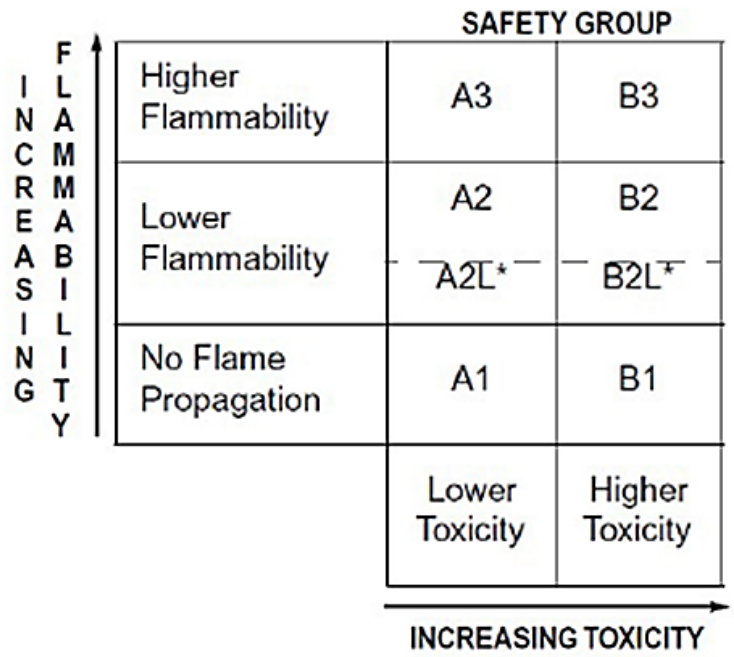

Figure 4. ASHRAE safety classification [16].

\subsection{Optimum Condition}

Optimum conditions are crucial in ORC analysis, in case of generally ORC has a low efficiency. According to We et al. [17] maximum output power will be obtained by utilization the remaining heat as much as possible. The excess steam temperatures and cooling water temperatures are standard value for cutting edge of medium-enthalpy geothermal applications [18].

In Figure 5, it can be seen the upper limit and the lower limit of the cycle is at temperature $68{ }^{\circ} \mathrm{C}$ and $10{ }^{\circ} \mathrm{C}$, respectively. However, in this study, a NIST Refprop database are used determine properties of each working fluids. The inlet turbine temperature of ORC is kept constant at $68^{\circ} \mathrm{C}$, which is the temperature limit is still below the limit of injection temperature to the reservoir $\left(70{ }^{\circ} \mathrm{C}\right)$, to avoid cross temperature in the evaporator. The evaporator pressure is varied as we can see at Figure 6, with the purpose is to discover the optimum condition of the cycle that produce the highest power and efficiency. The summary of the parameters that will be used in this ORC analysis, is presented in Table 2 . 


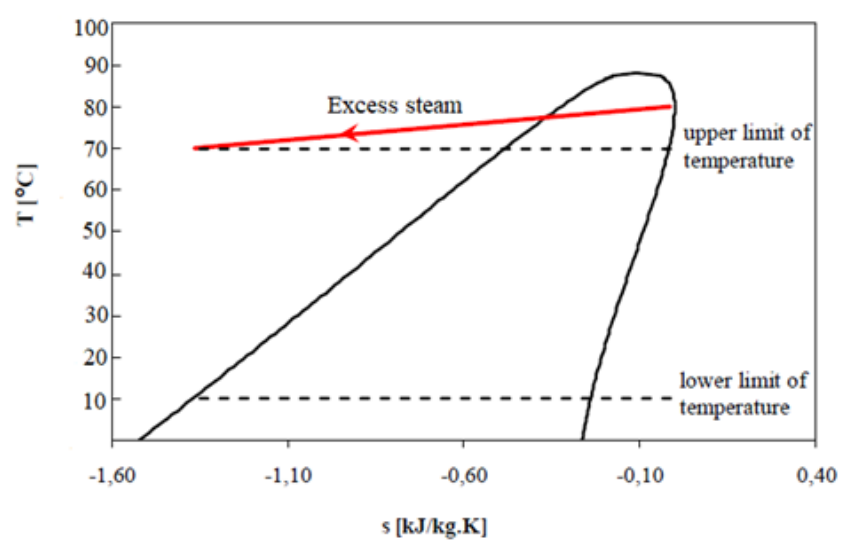

Figure 5. Process statement on T-s diagram of temperature limit of optimum condition.

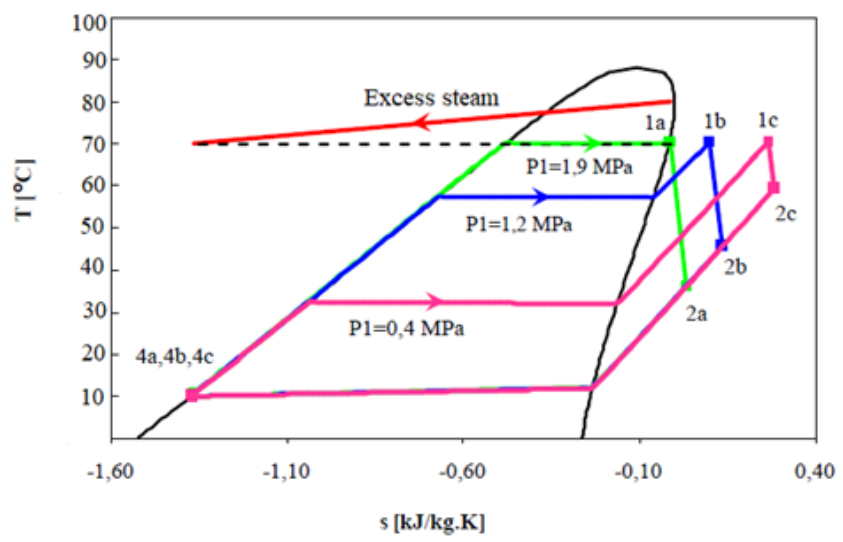

Figure 6. Process statement on T-s diagram of pressure variation.

Table 2. Parameters of ORC analysis.

\begin{tabular}{ll}
\hline ORC process parameters & \\
\hline Evaporation temperature & $68^{\circ} \mathrm{C}$ \\
Condensation temperature & $10^{\circ} \mathrm{C}$ \\
Pump efficiency & $90 \%$ \\
Turbine efficiency & $80 \%$ \\
Temperature difference in evaporator & $1 \mathrm{Kg} / \mathrm{s}$ \\
Mass flow rate cycle & \\
\hline Geothermal fluid parameters & \\
\hline Excess steam temperature & $80^{\circ} \mathrm{C}$ \\
Injection Temperature & $70^{\circ} \mathrm{C}$ \\
Pressure & $2-3 \mathrm{MPa}$ \\
Temperature at dead state & $5^{\circ} \mathrm{C}$ \\
Pressure at dead state & $0.101325 \mathrm{MPa}$ \\
\hline
\end{tabular}

\section{Result and Discussions}

This chapter will discuss the study results of the energy balance and exergy calculations from the ORC analysis using the equations in the previous chapter and include the several literatures to strengthen the results of the analysis.

\subsection{Result of Energy Performance}

This section discusses the energy performance characteristics of the ORC on the difference inlet pressure by involving the working fluids include R125, R143a, R22 and Propane. The calculation results are presented in Figure 7 and Figure 8.

Figure 7 shows the effect of evaporator pressure on the work net $\left(\dot{W}_{\text {net }}\right)$ of each working fluid based on energy balance calculation. It can be seen based on the graphs, the small pressure enters the turbine will produce a small power and efficiency, as well. Based on evaluation, it can be found that Propane is a working fluid that has the highest work net produce of $41 \mathrm{~kW}$ at a pressure of $2.48 \mathrm{MPa}$, and R125 has the lowest work net produce of $10.25 \mathrm{~kW}$ at the highest pressure of 3.6 MPa. This is because the expansion of the turbine work experienced by propane is greater than the other working fluids. This is in accordance with the supercritical ORC analysis carried out by Harmen et al. [19] which uses propane as work and produces the greatest power compared to other working fluids. Meanwhile Figure 8 shows the effect of evaporator pressure on thermal efficiencies of each working fluids based on energy balance equations. It can be seen from the graphic that the smaller the pressure that enters the turbine, the smaller thermal efficiency of the cycle can be achieved. Based on evaluation, it can be found that R22 is a working fluid that has the highest thermal efficiency of $12.12 \%$ at a pressure of $2.97 \mathrm{MPa}$, while the R125 has the lowest thermal efficiency of $8.17 \%$ at the highest pressure of 3.6 MPa. This is because the heat utilization of the evaporator as a heat provider with amount of $206.7 \mathrm{~kJ} / \mathrm{kg}$ can be utilised more by R22 compared to other working fluids.

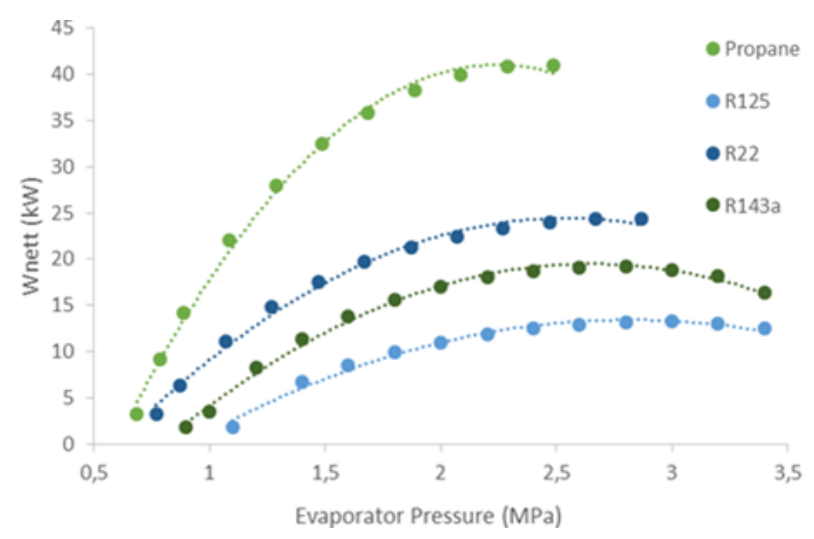

Figure 7. Performance result of pressure vs Wnet.

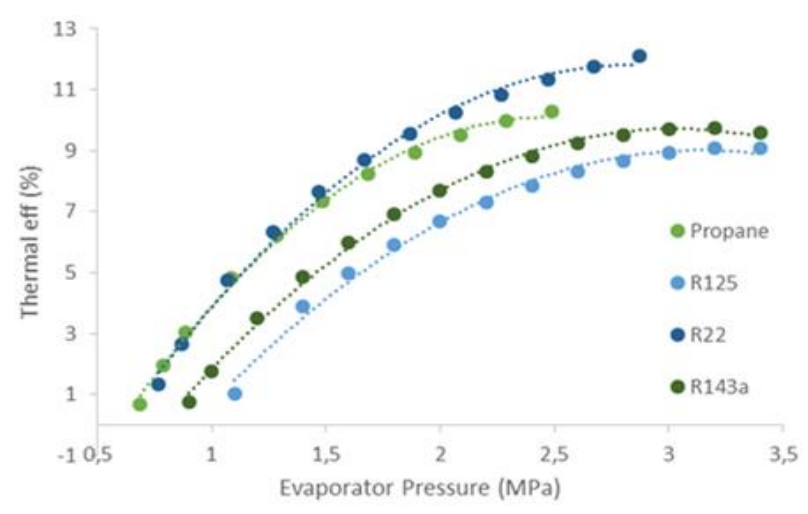

Figure 8. Performance result of pressure vs thermal efficiency.

Table 3. Work of cooling water pump.

\begin{tabular}{lllll}
\hline & \multicolumn{2}{c}{ Cycle tempo } & \multicolumn{2}{c}{ Calculation } \\
& $\dot{m}_{w}(\mathrm{~kg} / \mathrm{s})$ & $\dot{W}_{p w}(\mathrm{~kW})$ & $\dot{m}_{w}(\mathrm{~kg} / \mathrm{s})$ & $\dot{W}_{p w}(\mathrm{~kW})$ \\
\hline $\mathrm{R} 125$ & 10.94 & 3.10 & 5.95 & 1.94 \\
$\mathrm{R} 143 \mathrm{a}$ & 5.19 & 1.78 & 8.45 & 2.76 \\
R22 & 34.05 & 8.9 & 9.37 & 3.06 \\
Propane & 15.67 & 4.36 & 17.16 & 5.61 \\
\hline
\end{tabular}

Table 3 shows the amount of work required for the cooling water pump to drain water to the condenser whose, at highest performance, the initial cooling temperature is around $5{ }^{\circ} \mathrm{C}$ with assuming the pump Head $(H)$ is $3 \mathrm{~m}$. Calculations were performed using Eqs. (12)-(13) and 
compared with the results of the Cycle tempo simulation. It can be seen in Table 3, Propane requires a larger work of cooling water pump to flow cold water to the heat exchanger with amount of work around $5.61 \mathrm{~kW}$, while according to the cycle tempo simulation, R22 is a working fluid that requires a larger of cooling water pump power for flowing cold of 8.9 $\mathrm{kW}$.

\subsection{Results of Exergy Performance}

In the previous sections the amount of energy and efficiency that can be produced by each working fluid at different pressure variations has been discussed by using the first law thermodynamics approaching. However, there are weaknesses in using the first law of thermodynamic only, specifically the law does not take into account the decreasing of energy quality. That is the reason to carry on with the exergy analysis of the studied ORC plant. The main results of the exergy performance are shown in Figure 9 and Figure 10 .

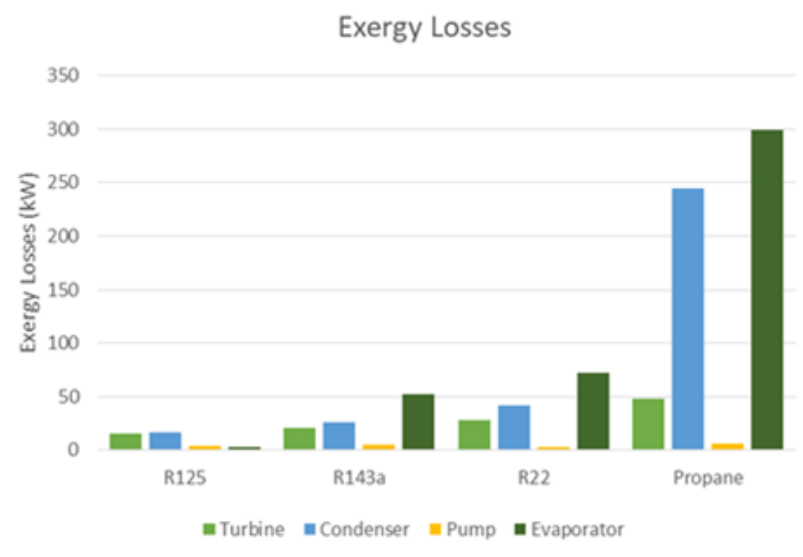

Figure 9. Component exergy losses.

Figure 9 shows that the greatest exergy losses in the ORC component was occurred in the evaporator, followed by condenser, turbine and pump. The highest exergy losses occurred in the evaporator during the heat exchange process. Meanwhile the evaporator that uses propane as its working fluid experiences the greatest exergy losses $(300 \mathrm{~kW})$, compared to the other working R125 has the lowest exergy losses.

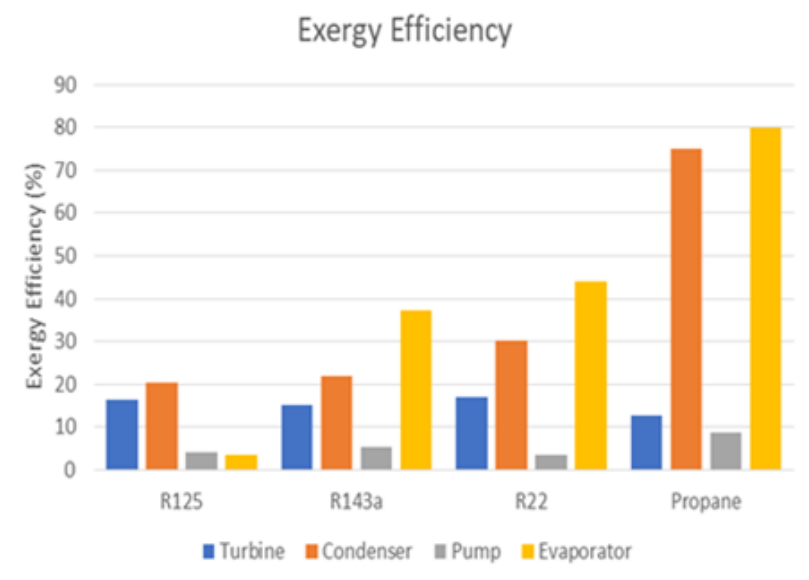

Figure 10. Component exergy efficiency.

Figure 10 shows the exergy efficiency all the ORC components of each working fluid and found that the propane's evaporator component produces the highest exergy efficiency $(79 \%)$ compared to other working fluids.
Contrarily, the pump is the component that has the lowest yield both in exergy losses and in exergy efficiency. Based on the calculation results it can be observed that the working fluid R22 produces the lowest exergy losses and exergy efficiency of $3.13 \mathrm{~kW}$ and $3.45 \%$ respectively. This is due to the low temperature increase at the pump so that the irreversibility of the pump is not large enough and resulting the exergy losses at the pump is low enough.

The statement concerning to the exergy analysis is strengthened by the data on Figures (11)-(14) which presents the exergy destruction of each component experienced by each working fluid. It can be stated that, almost all exergy destruction occurs in the evaporator, this is because the irreversible heat transfer process occurs in the evaporator. The working fluid of R125 has the highest exergy destruction in the evaporator compared to other working fluids at $83 \%$ followed by $73 \%$ (R143a), 61\% (Propane), 55\% (R143a), and $49 \%$ (R22). The same result occurred in the exergy analysis conducted by Abam et al. [20] comparing performance analysis in ORC based on exergy point of view with some arrangement cycle and the result is the highest percentage of exergy destruction occurs in evaporator followed by turbines. Meanwhile, the same result conducted by Darvish et al. [21] where the authors used R134a as the working fluid, and the result was that the boiler or evaporator was the component with the highest exergy destruction compared to other components at 59.7\%. Another research Gholamreza et al. [22] was conducted an exergy analysis on the combined heat and power (CHP) system at the petrochemical plant and found that boilers play an important role in exhausting exergy followed by turbines. Compared to exergy analysis in other research or previous study, it can be declared that our research results have been the same trends with the others.

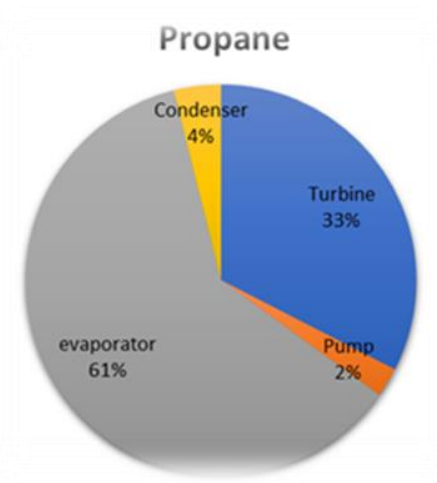

Figure 11. Percentage of exergy destruction of Propane.

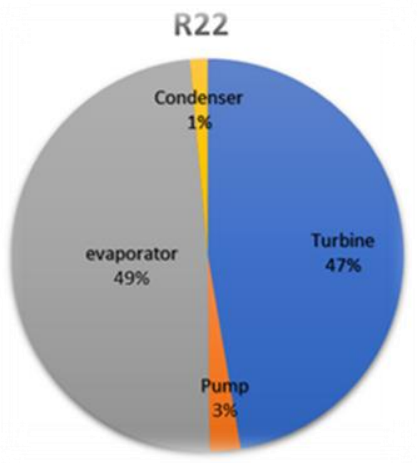

Figure 12. Percentage of exergy destruction of R22. 


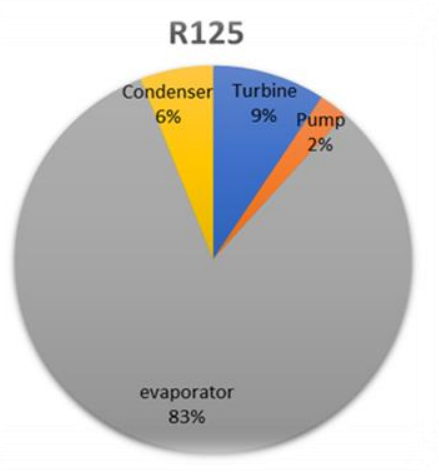

Figure 13. Percentage of exergy destruction on R125.

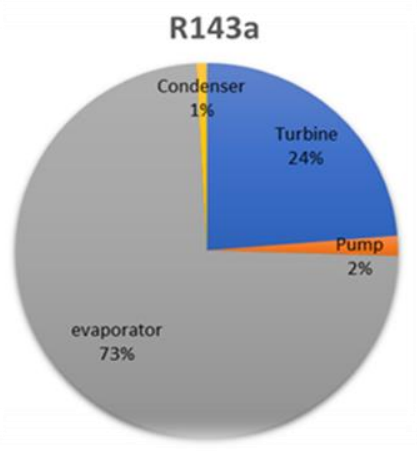

Figure 14. Percentage of exergy destruction of R143a.

\subsection{Result of Exergy Sustainability Indicators}

In this section, the role of exergy will be further discussed on the sustainability of the energy quality if the ORC system is applied to utilize excess steam from the Tura geothermal plant. The parameters used to measure ESI have been discussed in the previous section using Eqs. (28)-(31).

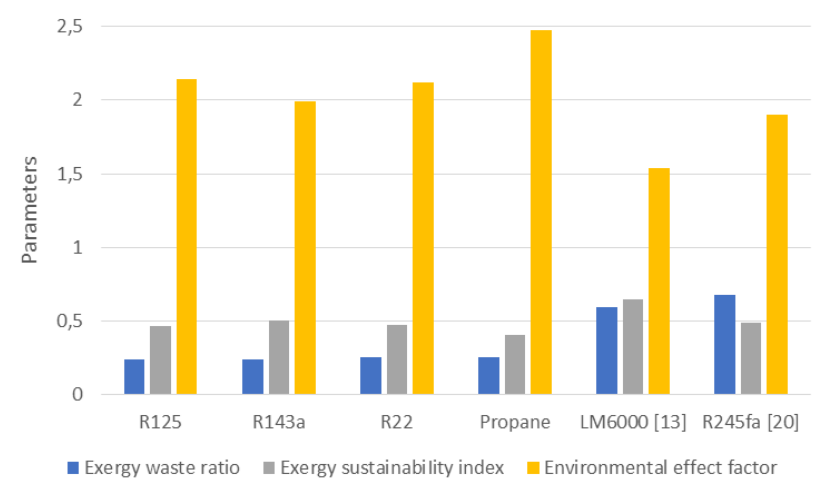

Figure 15. Exergy sustainability indicators of each working fluids.

Figure 15 shows the exergy sustainability of each working fluids which is represented by numerical parameter of exergy waste ratio (EWR), environmental effect factor (EEF), and exergy sustainability index (ESI) of each working fluids and two references as a comparison. EWR is the ratio of the overall waste exergy to the overall input exergy, while according to the calculation almost all working fluids have relatively the same EWR value, from 0.2397 to 0.2585 with Propane had the largest EWR value of 0.2585 and R125 had the lowest EWR value of 0.2397 . The size of the EWR value is relatively small compared to the research conducted by Aydin [13] on the turbine component and by Abam et al. [20] with the working fluid R245fa which produces EWR with values of 0.598 and 0.68 , respectively. Consequently, the
R125 had a minimum environmental influence compared to other working fluids.

The exergy sustainability index is a degree of sustainability and is elaborated as the complementary of the environmental effect factor [23]. In Figure 15, it can be seen that R143a had the highest ESI value of 0.5026 followed by $\mathrm{R} 125, \mathrm{R} 22$, and propane with value of $0.4669,0.4715$ and 0.4044 , respectively. Those value is relatively small compared to Aydin [13] and Abam et al. [20] with ESI value of 0.651 and 0.491 , respectively.

As last review is the environmental effect factor, it can be interpreted as the indicator of the system of environmental damage due to the waste exergy destruction [24]. Figure 15 show the EEF value of each working fluids, which Propane had the highest EEF value of 2.472 followed by R125, R22 and R143a with EEF values of 2.142, 2.121 and 1.989, respectively. In other hand, R143a had the smallest EEF value of among working fluids and it considered to be more sustainable.

\section{Conclusion}

Based on the thermodynamic evaluation, it can be concluded that the utilisation of heat from the excess steam of the Tura geothermal power-plant with ORC can be carried out with different working fluids.

- The results show that the Propane produces the highest net power around $47.5 \mathrm{~kW}$ with thermal efficiency of $10.3 \%$ at pressure of $2.49 \mathrm{MPa}$, while $\mathrm{R} 125$ produce the lowest net power around $11.4 \mathrm{~kW}$ with $8.9 \%$ at pressure of $3.65 \mathrm{MPa}$. This is due to the difference in enthalpy inlet and enthalpy outlet of the turbine in propane is greater than other working fluids.

- In this study, it is found that the exergy losses and exergy efficiency of the propane are the highest, i.e. $300 \mathrm{~kW}$ and $79 \%$, respectively.

- The highest exergy destructions in the ORC's components were occurred in the evaporator and turbine for all working fluids, i.e. 50-83\% and 9$47 \%$, respectively

- The environmental analysis involving ESI has been carried out which results in R125 having the lowest EWR value of 0.2397 where the impact on the environment is a minimum, while the highest ESI value and the lowest EEF value are generated by R134a with values of 0.5026 and 1.989 , respectively. It can be concluded that $\mathrm{R} 134 \mathrm{a}$ is considered to be more sustainable compared to other working fluids.

\section{Acknowledgements:}

This work was supported by the Stipendium Hungaricum Programme by the Doctoral School of Mechanical Engineering, Hungarian University of Agriculture and Life Science, Gödöllö, Hungary and the Department Mechanical Engineering, Institut Teknologi Nasional, Bandung, Indonesia.

$\begin{array}{ll}\text { Nomenclature } & \\ C_{p} & \text { Specific heat at pressure constant }(\mathrm{J} / \mathrm{kg} . \mathrm{K}) \\ e_{x} & \text { Exergy specific }(\mathrm{kJ} / \mathrm{kg}) \\ \dot{E}_{D} & \text { Exergy destruction }(\mathrm{kJ}) \\ \dot{E}_{X} & \text { Exergy }(\mathrm{kJ}) \\ \dot{E} X_{\text {in }}^{Q} & \text { Exergy heat input }(\mathrm{kJ}) \\ \dot{E} X_{\text {out }}^{Q} & \text { Exergy heat ouput }(k J)\end{array}$




$\begin{array}{ll}g & \text { Gravitational acceleration }\left(9.8 \mathrm{~m} / \mathrm{s}^{2}\right) \\ h & \text { Specific enthalpy }(\mathrm{kJ} / \mathrm{kg}) \\ H & \text { Head pump }(\mathrm{m}) \\ l n & \text { Logaritma natural } \\ \dot{m} & \text { Mass flow rate }(\mathrm{kg} / \mathrm{s}) \\ m_{w} & \text { Mass flow rate of cooling water }(\mathrm{kg} / \mathrm{s}) \\ P & \text { Pressure }(\text { Pa) } \\ P_{\text {crit }} & \text { Critical pressure }(\mathrm{MPa}) \\ P_{0} & \text { Pressure at dead state }(\mathrm{MPa}) \\ \dot{Q} & \text { Heat }(\text { W) } \\ R & \text { Universal gas constant }(8.3154 \mathrm{~J} / \mathrm{mol} . \mathrm{K}) \\ S & \text { Specific entropy }(\mathrm{kJ} / \mathrm{kg} . \mathrm{K}) \\ \dot{S}_{g e n} & \text { Rate of entropy generation } \\ T & \text { Temperature }\left({ }^{\circ} \mathrm{C}\right) \\ T_{0} & \text { Temperature at dead state }\left({ }^{\circ} \mathrm{C}\right) \\ T_{w} & \text { Temperature of cooling water }\left({ }^{\circ} \mathrm{C}\right) \\ \dot{W}_{p u m p} & \text { Volumetric flow rate }\left(\mathrm{m}^{3} / \mathrm{s}\right) \\ \dot{W}_{p w} & \text { Work on pump }(\text { W) } \\ \dot{W}_{\text {pwt }} & \text { Work on cooling water pump }(\mathrm{W}) \\ \dot{W}_{t u r b i n e} & \text { Work on cooling water pump theoretical }(\mathrm{W}) \\ \dot{W}_{\text {net }} & \text { Work on turbine }(\text { W) } \\ & \text { Work net }(\text { W) }\end{array}$

$\begin{array}{ll}\text { Greek symbols } & \\ \gamma & \text { Specific weight } \\ \eta & \text { Efficiency } \\ \psi & \text { Exergy efficiency } \\ \Sigma & \text { Summation }\end{array}$

$\begin{array}{ll}\begin{array}{l}\text { Subscripts } \\ \text { cond }\end{array} & \begin{array}{l}\text { condenser } \\ \text { crit }\end{array} \\ \text { evap } & \text { critical } \\ \text { exaporator } & \text { exergy } \\ \text { in } & \text { Inlet } \\ \text { net } & \text { net } \\ \text { out } & \text { outlet } \\ \text { pump } & \text { pump } \\ \text { pwt } & \text { water cooling pump theoritical } \\ \text { pw } & \text { water cooling pump } \\ \text { thermal } & \text { thermal } \\ \text { turbine } & \text { turbine } \\ 0 & \text { dead state }\end{array}$

$\begin{array}{ll}\text { Abbreviations } & \\ \text { ASHRAE } & \begin{array}{l}\text { American society of heating, refrigerating and } \\ \text { air conditioning engineers }\end{array} \\ \text { CHP } & \text { Combined heat and power } \\ \text { EEF } & \text { Environmental effect factor } \\ \text { ESI } & \text { Exergy sustainability indicator } \\ \text { EWR } & \text { Exergy waste ratio } \\ \text { GWP } & \text { Global warming potential } \\ \text { LEL } & \text { Lower explosive limit } \\ \text { MED } & \text { Multi effect desalination } \\ \text { NIST } & \text { National of institute standard and technology } \\ \text { ODP } & \text { Ozone depleting potential } \\ \text { ORC } & \text { Organic Rankine cycle } \\ \text { SRC } & \text { Solar Rankine cycle } \\ \text { TSI } & \text { Thermo sustainability index } \\ \text { UEL } & \text { Upper explosive limit }\end{array}$

\section{References:}

[1] A. Toth, N., Nyikos, A. Fenerty, K. David (2019). Prospects for Geothermal Power Projects in Hungary, Deen Haag, Netherlands: European Geothermal Congress 2019.

[2] Sohel, M. I. (2011). Thermodynamic Modelling and Simulation for High Efficiency Design and Operation of Geothermal Power Plants (Doctoroal dissertation), University of Canterbury, New Zealand.

[3] K. Boda, Fostering Geothermal Development in Hungary Opportunities and Bottlenecks, Iceland: UNU-GTP Report, 2016

[4] H. Jourhara, N. Khordehgah, S. Alhmahmoud, B. Delpech, A. Chauhan, S. A. Tassou, "Waste Heat Recovery Technologies and Applications", Thermal Science and Engineering Progress, doi: https://doi.org/10.1016/j.tsep.2018.04.017

[5] D.I. Permana, M.A. Mahardika, "Pemanfaatan Panas Buang Flue Gas PLTU Dengan Aplikasi Siklus Rankine Organik", Barometer, doi: http://dx.doi.org/10.35261/barometer.v4i2.1851

[6] C. Gianluca, V. Bori, A. Lazzaretto, G. Toniato, P. Danieli, "Experimental Investigation of an Innovative Biomass-Fired Micro-ORC System For Cogeneration Applications", Renewable Energy, doi:10.1016/j.renene.2020.07.012.

[7] D.I. Permana, I. Farkas, "Design and construction of organic Rankine cycle powered by solar thermal heat source", Book of Abstracts, 26th Workshop on Energy and Environment, Gödöllő, Hungary, December 10-11, 2020 .

[8] J.J. Brasz, J. J. Biederman, B. P. Holdman, "Power Production from a Moderate-Temperature Geothermal Resource", GRC annual meeting, Nevada, 2005

[9] H. Florian, B. Dieter, "Exergy Base Fluid Selection for a Geothermal ORC for Combined Heat and Power Generation", Appl. Therm. Eng. 30 (11) 2010, doi: 10.3390/en7074482

[10] S. Safa, M. H. Khoshgoftar Manesh, "Thermal and Exergetic Study of the Integrated Multi-Effect Desalination-Solar Rankine Cycle System for the Iranian Southern Coastal Region," Int. J. Thermo., doi: 10.5541/ijot. 776478

[11] M.J. Moran, H.N. Shapiro, Fundamental of Engineering Thermodynamics $6^{\text {th }}$ Ed. US: John and Wiley, 2008

[12] B.F. Tchanche, G.R. Lambrinos, A. Frangoudakis, G. Papadakis, "Exergy analysis of micro-organic rankine power cycles for a small scale solar driven reverse osmosis desalination system", Applied Energy, doi:10.1016/j.apenergy.2009.07.011.

[13] H. Aydin, "Exergetic sustainability analysis of LM6000 gas turbine power plant with steam cycle", Energy 57, 766-774, 2013. doi: http://dx.doi.org/10.1016/j.energy.2013.05.018 
[14] NIST REFPROP 9. Reference Fluid Thermodynamic and Transport Properties, Standard Reference Database. 23 NIST, 2008.

[15] Z. Ge, J. Li, Y. Duan, Z. Yang and Z. Xie, "Thermodynamic performance analyses and optimization of dual-loop organic rankine cycles for internal combustion engine waste heat recovery", Applied Sciences, doi: 10.3390/app9040680

[16] ASHRAE Update on new refrigerants designations and safety classifications [Online]. Available: https://www.ashrae.org/file\%20library/technical\%20re sources/refrigeration/factsheet_ashrae_english_20200 424.pdf (accessed July 4, 2021).

[17] D. Wei, X. Lu, Z. Lu and J. Gu, "Performance analysis and optimization of organic Rankine cycle (ORC) for waste heat recovery", Energy Conversion and Management, doi: 10.1016/j.enconman.2006.10.020

[18] Y. Nusiaputra, F. Qadri, D. Kuhn, H. Abdurrachim, "Empirical Correlation for Optimal Turbine Inlet Temperature and Pressure for Geothermal Sub-and Supercritical Organic Rankine Cyle”, Proceedings World Geothermal Congress, Melbourne, Australia, pp. 1-7, 2015.

[19] Harmen, A.D. Pasek, W. Adriansyah, Abdurrachim, "Thermodynamic Analysis of Supercritical Organic Rankine Cycle with Propane (R-290) as a Working Fluid". The 10thAUN/SEED-Net RC MEManuE, Phnom Penh, Cambodja, pp.86, 2019.
[20] F. Abam, E. Ekwe, S. Effiom and M. Ndukwu, "A comparative performance analysis and thermosustainability indicators of modified low-heat organic Rankine cycles (ORCs): An exergy-based procedure", Energy Reports, doi: 10.1016/j.egyr.2017.08.003

[21] K. Darvish, M. Ehyaei, F. Atabi and M. Rosen, "Selection of Optimum Working Fluid for Organic Rankine Cycles by Exergy and Exergy-Economic Analyses", Sustainability, doi: 10.3390/su71115362

[22] A. Gholamreza, T. Davood, A. Omidali, "Energy, Exergy and Environmental (3E) Analysis of the Existing CHP System in a Petrochemical Plant", Renewable and sustainable energy reviews 99, 234242, 2019. doi: https://doi.org/10.1016/j.rser.2018.10.009

[23] A. Midilli, I. Dincer, "Development of some exergetic parameters for PEM fuel cell for measuring environmental impact and sustainability", International Journal of Hydrogen energy 34, 3858-72. 2009. doi: http://dx.doi.org/10.1002/ep.10580

[24] A. Midilli, H. Kucuk, I. Dincer, Environmental and sustainability aspects of a recirculating aquaculture system, US: Wiley Online Library, 2011. 